\title{
CLINICAL STUDY AND SURGICAL MANAGEMENT OF RENAL STONE BY PERCUTANEOUS NEPHROLITHOTOMY
}

Jignesh Savsaviya1, Basavaraj Nagur², Sangeeta Biradar³, Anil Huddedar4, Trishant Chotai 5 , Aman Agrawal6, Abhinav Keswarwi 7 , Ankur Gopendra Das ${ }^{8}$

${ }_{1}^{1}$ Resident, Department of General Surgery, Krishna Institute of Medical Sciences University, Karad. ${ }^{2}$ Resident, Department of General Surgery, Krishna Institute of Medical Sciences University, Karad. ${ }^{3}$ Resident, Department of General Surgery, Krishna Institute of Medical Sciences University, Karad. 4 Professor, Department of Uro Surgery, Krishna Institute of Medical Sciences University, Karad. ${ }^{5}$ Resident, Department of General Surgery, Krishna Institute of Medical Sciences University, Karad. ${ }^{6}$ Resident, Department of General Surgery, Krishna Institute of Medical Sciences University, Karad. ${ }^{7}$ Resident, Department of General Surgery, Krishna Institute of Medical Sciences University, Karad. ${ }^{8}$ Resident, Department of General Surgery, Krishna Institute of Medical Sciences University, Karad.

\section{ABSTRACT}

\section{BACKGROUND}

Although stone disease is one of the most common afflictions of modern society, it has been described since antiquity. Urinary stone disease has perplexed the physicians for many centuries. Even today in spite of sophisticated research techniques and expand understanding of disease process, urinary calculi are major problems.

\section{OBJECTIVES}

1. To study the mode of clinical presentation of renal stone.

2. To study the preoperative and postoperative haematological test.

3. To study the preoperative and postoperative renal function test.

\section{METHODS}

50 patients diagnosed as renal stone more than $2.5 \mathrm{~cm}$ in size above pelvi-ureteric junction and admitted for Percutaneous Nephrolithotomy (PCNL) surgery in KIMS, Karad, during period Dec. 2013 to June 2015.

\section{RESULTS}

Mean age of presentation was 43.56+13.98 years. Incidence more in males 34 (68\%) than females 16 (32\%); 24 (48\%) patients diagnosed as left renal calculi, $24(48 \%)$ patients as right renal calculi and 2 (4\%) patients as bilateral renal calculi; 31 (62\%) patients were Non-vegetarian and $19(38 \%)$ were Vegetarian; $30(60 \%)$ patients were using borewell water and $20(40 \%)$ patients were using tap water. All the patients presented with pain abdomen; $80 \%$ had burning micturition and $28 \%$ had Haematuria. The fall in mean Haemoglobin (Hb) was $0.78 \mathrm{gm} / \mathrm{dL}$ and fall in Mean Packed Cell Volume (PCV) was 2.33\%, which was statistically significant. Fall in mean serum creatinine was $0.21 \mathrm{mg} \%$, which suggested improvement in creatinine clearance.

\section{CONCLUSION}

Renal stone show a peak incidence in the 5 th decade accounting for $36 \%$ of cases. Post-operatively, Hb, PCV and Creatinine done after 48 hours which show drop in mean HB was $0.78 \mathrm{~g} / \mathrm{dL}$ and drop in mean PCV was $2.34 \%$ suggested minimal blood loss during surgery. Fall in mean serum creatinine was $0.21 \mathrm{mg} \%$, which suggested improvement in creatinine clearance after PCNL surgery.

\section{KEYWORDS}

Renal Stone, Haemoglobin, Creatinine, PCNL.

HOW TO CITE THIS ARTICLE: Savsaviya J, Nagur B, Biradar S, et al. Clinical study and surgical management of renal stone by percutaneous nephrolithotomy. J. Evolution Med. Dent. Sci. 2016;5(66):4696-4698, DOI: 10.14260/jemds/2016/1070

\section{INTRODUCTION}

Stone formation is usually a result of urinary super saturation. Decreased fluid intake and consequent urine concentration are among the most important factors influencing stone formation. The hot arid areas, diet, physical activity and corporeal overweight could be other reasons.1,2 Percutaneous

Financial or Other, Competing Interest: None.

Submission 05-04-2016, Peer Review 09-06-2016,

Acceptance 14-06-2016, Published 16-08-2016.

Corresponding Author:

Dr. Basavaraj Nagur,

Room No. 20, IHR Hostel,

KIMS University, Karad, Satare,

Maharashtra.

E-mail: sachin.nagur@gmail.com

DOI: $10.14260 /$ jemds/2016/1070 approach to kidney was first described in 1955 by Goodwin and Colleague. ${ }^{3}$ Percutaneous Nephrolithotomy is an integral component of the management of large-volume renal calculus disease.

\section{MATERIAL AND METHOD}

This is clinical study of cases of renal stone who has been admitted for PCNL Surgery to Urology Unit of General Surgery in Krishna Hospital, KIMS, Karad, during the period of Dec. 2013 to June 2015 over a span of 18 months.

The Selection of Patients was done with the Following Criteria

\section{Inclusion Criteria}

All patients diagnosed as more than $2.5 \mathrm{~cm}$ in size of renal stone above pelvi-ureteric junction and admitted for PCNL surgery. 


\section{Exclusion Criteria}

Renal stone in immunocompromised patient.

The patients were asked details of history. A detailed general physical examination and systemic examination done. Investigation like preoperative and postoperative haemoglobin, packed cell volume and creatinine, ultrasonography abdomen, X-ray KUB and intravenous pyelography were obtained.

Ethical clearance has been obtained from Research and Dissertation Committee/Ethical Committee of the Institution for this study. Patients were prepared for PCNL under General anaesthesia or spinal anaesthesia depending upon general condition.

Postoperative care was meticulously followed; intake and output charts and vital signs charts were maintained. Patients were given antibiotics, analgesics and sedation. Most of the patients had uneventful recovery. Nephrostomy drains were removed between $3^{\text {rd }}$ to $5^{\text {th }}$ postoperative days. Patients were advised to come for follow-up in OPD after 5 days from discharge and follow-up period was 2 weeks. Patients were asked for symptoms like pain, haematuria and urinary tract infection.

\section{RESULT}

In our study, the age of patients ranged between 11 and 70 years. The maximum number of renal stone was found to be in the age group between 40 and 49 years, i.e. 18 (36\%) cases. (Shown in the Tab 1) The average age of presentation is $43.56 \pm 13.98$ year, majority of patients were male (34). The sex incidence in the present study is 2.15:1. There were $34(68 \%)$ males and $16(32 \%)$ females out of 50 patients. In this study $24(48 \%)$ patients were diagnosed of left renal calculi, 24 $(48 \%)$ patients of right renal calculi and $2(4 \%)$ patients of bilateral renal calculi and $31(62 \%)$ patients were Nonvegetarians and 19 (38\%) patients were Vegetarians.

In our study, $30(60 \%)$ of the 50 patients were using borewell water. The remaining $20(40 \%)$ patients were using tap water for drinking and all the patients presented with pain abdomen; $80 \%$ of the patients had Burning micturition, 28\% of the patients had Haematuria, vomiting (24\%), Pyuria (4\%) and Fever $(2 \%)$ were other common symptoms. (Shown in Graph 1). USG detected renal stone in $100 \%$ of patients. KUB $\mathrm{X}$-ray was positive in $100 \%$ of patients. In our study, IVP done in only 47 (94\%) patients and there were 100\% positive result.

In this study, the mean pre-operative haemoglobin concentration was $11.98 \mathrm{gm} / \mathrm{dL}$ (Range: $7.50 \mathrm{gm} / \mathrm{dL}$ - 16 $\mathrm{gm} / \mathrm{dL}$ ) and post-operatively the mean haemoglobin concentration was $11.20 \mathrm{gm} / \mathrm{dL}$ (Range: $8.80 \mathrm{gm} / \mathrm{dL}-13.50$ $\mathrm{gm} / \mathrm{dL}$ ). The fall in mean haemoglobin concentration was 0.78 $\mathrm{gm} / \mathrm{dL}$, which was statistically significant $(\mathrm{p}=0.0031)$. (Shown in the Tab 2) and the mean pre-operatively packed cell volume was $36.45 \%$ (Range: $27.5 \%-50 \%$ ) and post-operatively the mean packed cell volume was $34.11 \%$. (Range: $27.3 \%-43 \%$ ). The fall in mean packed cell volume was $2.33 \%$, which was statistically significant $(\mathrm{p}=0.0001)$.

In our study, pre-operatively mean serum creatinine 1.35 $\mathrm{mg} \%$ with range of $0.7 \mathrm{mg} \%-6.5 \mathrm{mg} \%$. Post-operatively, the mean serum creatinine falls to $1.14 \mathrm{mg} \%$ with the range of 0.7 $\mathrm{mg} \%-2.4 \mathrm{mg} \%$. The fall in mean serum creatinine was 0.21 $\mathrm{mg} \%$, which was statistically significant $(\mathrm{p}=0.0500)$. (Shown in the Tab 3) and 8 of 50 patients who had serum creatinine values above $1.4 \mathrm{mg} / \mathrm{dL}$ before PCNL and were considered to have impaired renal function. After PCNL, only 3 patients had creatinine value remained above $1.4 \mathrm{mg} / \mathrm{dL}$ with range of 0.7 $\mathrm{mg} \%-2.4 \mathrm{mg} \%$, which suggested renal function was improved after PCNL.

\begin{tabular}{|c|c|c|}
\hline Age Groups & No. of Patients & \% of Patients \\
\hline$<=29$ yrs & 9 & 18.00 \\
\hline $30-39$ yrs & 11 & 22.00 \\
\hline $40-49$ yrs & 18 & 36.00 \\
\hline$>=50$ yrs & 12 & 24.00 \\
\hline Total & $\mathbf{5 0}$ & $\mathbf{1 0 0 . 0 0}$ \\
\hline \multicolumn{2}{|c|}{ Table 1: Distribution of Patients by Age Groups } \\
\hline
\end{tabular}

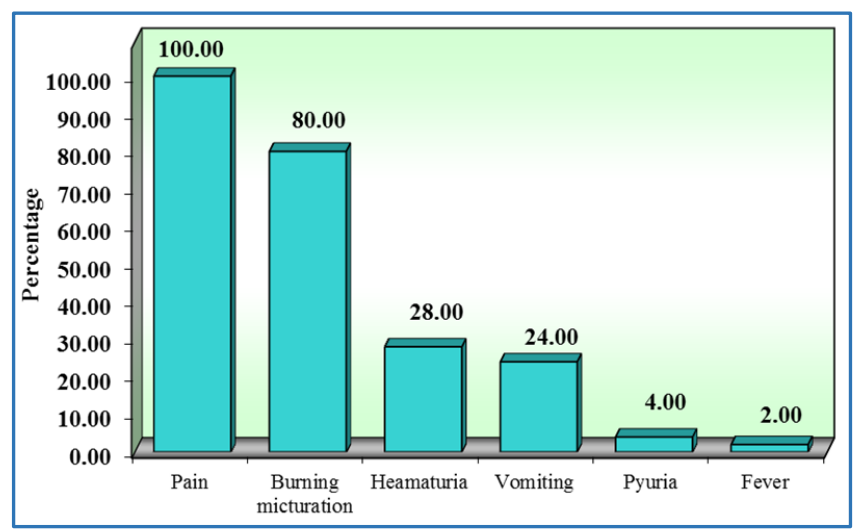

Graph 1: Distribution of Patients with Presence of Various Symptoms

\begin{tabular}{|c|c|c|c|c|c|c|}
\hline Time & Mean & $\begin{array}{c}\text { Std. } \\
\text { Dv. }\end{array}$ & $\begin{array}{c}\text { Mean } \\
\text { Diff. }\end{array}$ & $\begin{array}{c}\text { SD } \\
\text { Diff. }\end{array}$ & Paired t & p-value \\
\hline $\begin{array}{c}\text { Pre- } \\
\text { operative }\end{array}$ & 11.98 & 1.69 & & & & \\
\hline $\begin{array}{c}\text { Post- } \\
\text { operative }\end{array}$ & 11.20 & 1.08 & 0.78 & 1.76 & 3.1100 & 0.0031 \\
\hline \multicolumn{6}{|c|}{ Table 2: Comparison of Pre-and Post-Operative } \\
Haemoglobin Scores by Paired 't' Test
\end{tabular}

\begin{tabular}{|c|c|c|c|c|c|c|}
\hline Time & Mean & $\begin{array}{l}\text { Std. } \\
\text { Dv. }\end{array}$ & $\begin{array}{c}\text { Mean } \\
\text { Diff. }\end{array}$ & $\begin{array}{c}\text { SD } \\
\text { Diff. }\end{array}$ & Paired t & p-value \\
\hline $\begin{array}{c}\text { Pre- } \\
\text { operative }\end{array}$ & 1.35 & 0.91 & \multirow{2}{*}{0.21} & \multirow{2}{*}{0.76} & \multirow{2}{*}{1.9995} & \multirow{2}{*}{0.0500} \\
\hline $\begin{array}{c}\text { Post- } \\
\text { operative }\end{array}$ & 1.14 & 0.33 & & & & \\
\hline$T a b$ & $\begin{array}{l}\text { 3: Col } \\
\text { Crea }\end{array}$ & ne & $\begin{array}{l}f P r \\
e s b\end{array}$ & $\begin{array}{l}\text { Ind } \\
\text { aire }\end{array}$ & $\begin{array}{l}\text { t-Oper } \\
\text { Test }\end{array}$ & \\
\hline
\end{tabular}

\section{DISCUSSION}

Total 50 patients were studied in the present study. Their data has been analysed and discussed below.

In the present study, renal stone show peak incidence in the $5^{\text {th }}$ decade according to $36 \%$ of the cases. The average of presentation is $43.56 \pm 13.98$ years with a range of $11-70$ years. In a study by Mahmoud M Shalaby et $\mathrm{al}^{4}$, mean age was $42 \pm 13.2$ years and range 18-67 years and Hyder et al ${ }^{5}$ study showed mean age was $42.43 \pm 13.17$ years and range $20-75$ years.

Renal stone occurred predominantly in males compared to female. As compared with other studies, Sarhad Khan et al ${ }^{6}$ series showed $70 \%$ males and $30 \%$ females were affected. In 
another study by Hyder et al, males $71.75 \%$ and female $28.24 \%$ were affected. Renal stone occurred predominantly in males and was almost twice more common than females in our study; $68 \%$ of patients in our study were males and $32 \%$ were females. This is similar to study by Sarhad Khan et al, where males affected were $70 \%$ and female affected were $30 \%$. The male preponderance is probably due to increased testosterone levels, which results in increased endogenous oxalate formation. Males are engaged more in the outdoor occupation, which may result in dehydration and urinary concentration. Increased urinary citrate in females may aid in protecting females against urolithiasis. ${ }^{7}$

In our study, $62 \%$ patients were non-vegetarian and $38 \%$ patients were vegetarian. Some reports have described that vegetarians are at lower risk for stone formation in contrast to non-vegetarians (Robertson et al 1982). The role of animal protein and potassium intake in the aetiology of calcium stone formation is paradoxical. Some studies have shown a positive association between animal protein intake and stones (Curhan et al 2004). The consumption of a diet rich in animal protein (from meat, dairy, poultry or fish), sodium (Muldowney et al 1982, Silver et al 1983, Sabto et al 1984) and refined sugars increases urinary calcium and uric acid concentrations and lowers urinary citrate concentration. Kidney stones formers have been reported to process sugar abnormally (Rao et al 1982) by increasing urinary oxalate (Li et al 1986) and urinary calcium as well (Lemann et al 1969). ${ }^{8}$

In our study, pain was the most common complaint noticed in $100 \%$ patients of renal stone; $80 \%$ of the patients had burning micturition and $28 \%$ of the patients had haematuria. A similar study by Gaurav Rai Sharma et al $^{9}$ showed main presenting symptom was pain $(96.3 \%) ; 85 \%$ of the patients had burning micturition and $30 \%$ of patients had haematuria.

Plain X-ray KUB was able to demonstrate calculi in 100\% of cases, which is similar to the study by KK Malhotra et al.10 Ultrasound (US) was a cheap, non-invasive, safe technique, which can detect acute urinary tract obstruction with a sensitivity of $91-92 \%$ and a specificity of $90 \%$. Intravenous Urography (IVU) is the gold standard investigation providing information regarding the site and degree of obstruction, size of stone and the effect of obstruction on the renal excretion. ${ }^{11}$

In our study, $52 \%$ patient operated as right PCNL and $48 \%$ operated for left PCNL. These results are similar to those reported by Sarhad Khan et al6, as right PCNL 55\% and left PCNL 45\%.

In our study, mean $\mathrm{Hb}$ and PCV drop were $0.78 \mathrm{~g} / \mathrm{dL}$ and 2.33\% respectively following PCNL. Compared with Rajesh Kukreja et al ${ }^{12}$ showed mean Hb and PCV drop was $1.01 \mathrm{~g} / \mathrm{dL}$ and $2.8 \%$ respectively. Compared with other study, which signifies least $\mathrm{Hb}$ and PCV drop during our procedure means blood loss very less. Significant falls in mean serum creatinine
(0.21 mg\%) was demonstrated following the stone removal. This shows improvement in renal function with fall in creatinine in all patients. None of the patients showed deterioration of renal function. S. Gupta et $\mathrm{al}^{13}$ had shown significant fall in mean serum creatinine $(0.33 \mathrm{mg} \%)$ after stone removal.

\section{REFERENCES}

1. Portis AJ, Sundaram CP. Diagnosis and initial management of kidney stones. Am Fam Physician 2001;63(7):1329-39.

2. Bartoletti R, Cai T, Mondaini N, et al. Epidemiology and risk factors in urolithiasis. Urol Int 2007;79(1):3-7.

3. Goodwin WE, Casey WC, Woolf W. Percutaneous trocar (needle) nephrostomy in hydronephrosis. J Am Med Assoc 1955;157(11):891-4.

4. Shalaby MM, Abdalla MA, Aboul-Ella HA, et al. Single puncture percutaneous nephrolithomy for management of complex renal stones. BMC Research Notes 2009;2(1):62.

5. AL-Aridy HM. Percutaneous nephrolithotomy for renal calculi: a single surgeon experience. The Iraqi Postgraduate Medical Journal 2013;12(4):576-80.

6. Khan S, Toori LA, Anwer K. The efficacy of percutaneous nephrolithotomy in renal and upper ureteric calculi. Pakistan J Med Res 2005;44(2):89-91.

7. Robertson WG. Epidemiology of urinary stone disease. Urol Res 1990;18(1):3-8.

8. Abbagani S, Gundimeda SD, Varre S, et al. Kidney stone disease: aetiology and evaluation. International Journal of Applied Biology and Pharmaceutical Technology 2010;1(1):175-82.

9. Sharma GR, Dwivedi S, Bhatia B, et al. Clinical presentations of urolithiasis: a prospective study in referral centre. IOSR 2014;13(3):83-5.

10. Malhotra KK. Medical aspects of renal stones. JIACM 2008;9(4):282-6

11. Arif P. Urinary stone survey at Quetta division hospitals with reference to drinking water. (Dissertation). Lahore; Punjab University, 1992.

12. Kukreja R, Desai MM, Patel S, et al. Factors affecting blood loss during percutaneous nephrolithotomy: prospective study. Journal of Endourology 2004;18(8):715-22.

13. Gupta S, Wadhwa P, Minocha VR. Renal function response following percutaneous nephrolithotomy in patients of renal stone disease with impaired renal function. IJNM 2002;17(1):18-20. 